\title{
A Comparative Analysis of Black Racial Group Consciousness in the United States and Britain
}

\author{
Ayobami Laniyonu \\ Centre for Criminology and Sociolegal Studies, University of Toronto
}

\begin{abstract}
Extant scholarship on black politics has demonstrated the mobilizing effect that racial group consciousness can have on African American political participation. Few studies, however, test for or compare the political impact of group consciousness across national contexts. This paper presents an empirical comparison of group consciousness and its relationship with political behavior among black Americans and black Britons. Mobilizing two nationally representative surveys from the United States and Britain and a multi-dimensional measure of group consciousness, the findings presented here suggest that while elements of racial group consciousness are present among blacks in both societies, racial group consciousness is generally more prevalent and politically significant among blacks in the United States. For example, blacks in Britain are less likely to view blacks as occupying a fundamentally marginalized structural position and less likely to endorse race specific interventions that might address that marginalization. Results from regression analysis further suggest that while strong racial (rather than national) group attachment negatively affects the likelihood that blacks will vote in both countries, other elements of group consciousness are more strongly associated with participation among blacks in the United States than in Britain.
\end{abstract}

Key words: Racial group consciousness, African American politics, Black British politics, Black Politics.

To what extent does racial group consciousness exist in black communities outside the United States, and how does the relationship between group consciousness and political behavior vary across national contexts? ${ }^{1}$ The relationship between black racial identity and political behavior is one

Address correspondence and reprint requests to: Ayobami Laniyonu, Centre for Criminology and Sociolegal Studies, University of Toronto. E-mail: alaniyonu@gmail.com 
of the most well studied in American political science. Studies in this literature have frequently shown that racial identity, processes of racialization, and experiences with anti-black discrimination affect a broad range of political attitudes and behaviors, such as voting, membership in political and civic organizations, participation in protests and demonstrations, party choice, and policy preferences (Chong and Rogers 2005; Hutchings and Valentino 2004; Miller et al. 1981; Smith 2013). Within this literature, scholarship on racial group consciousness has drawn particular attention, arguably because it specifies a clear mechanism linking racial identification to political behavior, especially participation in mass movements like the U.S. Civil Rights movement and the Black Power movement (Chong and Rogers 2005; Miller et al. 1981).

Despite racial group consciousness' extensive application to the study of black American politics, however, relatively few studies have explored the extent to which group consciousness affects the political behavior of black groups outside the United States. Indeed, much of the current literature has been derived specifically from the study of native-born African Americans, to the exclusion of other black groups inside the United States. Cognizant that differences in ethnicity, racial socialization, and migratory experience might affect racial group consciousness among blacks in the United States, recent scholarship has explored group consciousness' prevalence and political consequences among $1^{\text {st }}$ and $2^{\text {nd }}$ generation black immigrants. These studies have found that while black immigrants generally express levels of racial group consciousness similar to native-born African Americans, its prevalence and effect on political behavior and policy preferences does vary by ethnicity, migratory experience, and generational status (Capers and Smith 2016; Greer 2013; Rogers 2006; Smith 2013).

Pushing the literature beyond the United States, a handful of crossnational studies like Paschel's (2016) comparison of black movements in Colombia and Brazil and Nelson's (2000) comparison of black politics in Boston and Liverpool have provided evidence of racial group consciousness at work beyond the United States and outside the African American community. Paschel's (2016) work in particular demonstrates the ability of group consciousness to secure significant social and political gains for Afro-descendant people in national contexts where state and other discourses have argued that race matters less for blacks (Bourdieu and Wacquant 1999). Thus, while we might expect racial group consciousness to be more prevalent and politically impactful in the United States, racial group consciousness is likely at work beyond it. These works suggest that a 
failure to consider racial group consciousness in other national contexts may amount to omitting meaningful cases in the analysis of how practices of racial identification, anti-black discrimination, and social exclusion affect racial politics across the range of multi-racial/multi-ethnic liberal democracies, and may obscure the cross-national, international, and transnational dimensions of black politics (Hanchard 2003; Hanchard and Chung 2004; Paschel 2016; Paschel and Sawyer 2008).

With that in mind, this paper presents an empirical comparison of racial group consciousness and its political consequences for black citizens and residents in the United States and Britain, which together present an interesting and useful comparative pair. On the one hand, the countries are sufficiently similar-as economically advanced, liberal, and democratic societies-that comparison of black politics can be made without attributing observed differences to differences in the role that race and ethnicity can play in developing, non-democratic, or semidemocratic nations, or to the constrained possibilities for political action in semi or non-democratic regimes (Saideman et al. 2002). Similarly, both countries are majority white-Anglo nations, historically influenced by racist ideologies that emphasized social distance and exclusion of blacks and other non-white groups (Goldberg 2002). This distinguishes them from other nations, such as Colombia and Brazil, where Afro-descendant groups constitute large pluralities of the population, and where the dominant official discourse has been one of the racial mixture (Wade 1997). Thus, a comparison of racial group consciousness in the United States and Britain is a comparison in contexts where the formal capacity to engage in various forms of political action (such as voting) and the meaning and significance of those actions are shared. Similarly, it is a comparison in contexts where the meaning attributed "black" or anti-black racism is more or less shared.

At the same time, racial politics in the United States and Britain have progressed differently and the black population in the two countries vary along a sufficient number of dimensions relevant to group consciousness to warrant empirical comparison. For example, although blacks constitute numeric minorities in both nations, the absolute size of the black population is significantly smaller in Britain, potentially limiting the amount of racial threat felt by whites and thereby their impetus to develop institutions and practicessuch as Jim Crow - which facilitated the development of racial group consciousness in the United States and motivated collective action (Blalock 1967; Miller et al. 1981). The black population in Britain is also more ethnically plural-constituted by migratory streams from a broad set of 
Caribbean and African nations-which may undermine the strength of a singularly racial identity and thereby group consciousness (Masuoka 2006).

Using two nationally representative surveys from the United States and Britain, this analysis presents an explicit comparison of the prevalence of racial group consciousness in the United States and Britain and a comparison of group consciousness' effect on political participation. This study adopts a design which leverages to the furthest extent possible similar question wording across the two surveys to test a multi-dimensional operationalization of racial group consciousness. This operationalization of racial group consciousness - comprised of measures of racial identification, perception of marginalized group status, and belief in the necessity of political action to remedy marginalization - allows for a more detailed comparison of group consciousness in the two national contexts than would be possible using other measures of consciousness (such as linked fate) and indeed, may be a more valid measure when studying racial group consciousness beyond African Americans (Sanchez and Vargas 2016).

Overall, the results of the analysis reveal interesting similarities but important differences in racial group consciousness among blacks in the United States and Britain. Generally, the findings demonstrate the presence of racial group consciousness among blacks in Britain, but at the same time suggest that it is less widespread and less political impactful among average citizens in Britain than in the United States. For example, while blacks in Britain evince comparable levels of racial (as opposed to national) identification as blacks in the United States, they appear less likely to believe that blacks occupy a fundamentally marginalized position in society and less likely to support government intervention specifically on behalf of blacks. Regression analysis similarly suggests that while strong racial identity is negatively associated with voter turnout out in both countries, only in the United States are perceptions of group marginalization associated with a higher likelihood of voter turnout. Implications and suggestions for further research are discussed in the conclusion.

\section{BLACK GROUP CONSCIOUSNESS IN THE UNITED STATES}

The concept of black group consciousness was first motivated by research interested in explaining patterns of political participation among African Americans during the 1960s and 1970s. This research demonstrated that 
when controlling for socioeconomic status, African American political participation exceeded that of white Americans, despite recent de facto political enfranchisement in the American South and significant socioeconomic marginalization throughout the country (Olsen 1970; Verba and Nie 1972). Early empirical results found group consciousness motivated a variety of forms of political behavior, including turning out to vote in presidential elections, contacting elected officials, and participation in political campaigns (Miller et al. 1981). Borrowing explicitly from Marxist notions of class consciousness, racial group consciousness was conceptualized by some early studies in the literature as signaling high levels of awareness of one's own subordinated racial position, white supremacy and anti-black social structure, and the importance of collective political action as a remedy (Miller et al. 1981, 495).

Empirical operationalization of racial group consciousness has varied dramatically since its introduction, however, potentially resulting in an inconsistent pattern of empirical results (Chong and Rogers 2005). One popular proxy or measure for racial group consciousness in the literature has been the linked fate measure, which asks survey respondents the extent to which they believe that what happens to other blacks matters for their own life chances and captures Dawson's (1994) argument that individual black Americans use the social positioning of black Americans as a group to make judgments and form political decisions. A broad literature has found linked fate to be associated with a range of attitudes and behaviors, including community nationalism and womanist ideology, support for affirmative action policies, and neighborhood preference (Gay, Hochschild and White 2016, 123.). Recent scholarship, however, has questioned the validity of linked fate as a proxy for racial group consciousness (Chong and Rogers 2005; McClain et al. 2009). For example, while high levels of linked fate might capture a sense of inter-dependency among black people that would be produced with high levels of group consciousness, it is not clear that the measure adequately captures perceptions of group subordination and beliefs in the necessity of political action.

Departing from the linked fate heuristic, recent scholarship has encouraged conceptualization of racial group consciousness as a multidimensional attitude that combines: (1) individual identification with the racial group, (2) belief that blacks constitute a disadvantaged social group, and (3) subscription to attitudes which identify some political ideology or strategy as necessary for rectifying that disadvantage. For example, McClain et al. (2009, 474) define group identification as, 
"an individual's awareness of belonging to a certain group and having a psychological attachment to that group based on a perception of shared beliefs, feelings, interests, and ideas with other group members". Group identification is conceptually distinct from racial group consciousness, however, which in addition captures attitudes or perceptions of the group's social status along with a subscription to a set of beliefs that political action is needed to rectify that status. Thus, Chong and Rogers (2005, 350) argue that consciousness is, "in-group identification with a set of ideas about the group's status and strategies for improving it" while McClain et al. $(2009,476)$ similarly argue that "group consciousness is in-group identification politicized by a set of ideological beliefs about one's group's social standing, as well as a view that collective action is the best means by which the group can improve its status and realize its interest". This latter definition arguably conflates mass contentious collective action, such as protests and demonstrations, with political action generally. As Paschel (2016) identified in Latin America, for example, conscious groups can and have engaged in a diverse set of political strategies to remedy their marginalization, and scholarship on racial group consciousness has considered modes of political mobilization beyond mass movements (see also Lee (2008)).

Consistent with this, Chong and Rogers (2005) tested the association of this multi-dimensional construction of racial group consciousness with various modes of political participation in the 1984 National Black Election Survey (NBES). Across the three dimensions of racial group consciousness, the authors found that racial group identification and perception of black marginalization were positively associated with voter turnout, with perception of group marginalization exhibiting a much stronger association with voter turnout than racial group identification. No relationship was uncovered between the perception of discrimination or subscription to collective strategies and voter turnout. Looking beyond voter turnout, the authors uncovered a more general pattern in which different elements of group consciousness shared different relationships with other forms of political participation. For example, racial group identification was more powerfully associated with demonstrating, picketing, or boycotting, than it was with voter turnout. Across a range of indicators of political participation, however, perception of discrimination and support for collective strategies were generally unrelated to political participation. In a related study conducted among Latinos, Stokes (2003) similarly found a positive association between both racial identification and perception of group disempowerment, and political participation, but uncovered variability 
among different Latino ethnic groups in which elements of group consciousness were associated with political participation.

Though arguably more conceptually valid and detailed than other measures of racial group consciousness, this multi-dimensional approach does have some disadvantages, namely the difficulty in associating its multiple indicators to a singular indicator of political action (see for example Miller et al. 1981). Nevertheless, such an approach can be illustrative, especially for comparative analyses. Under this framework, all three components are needed in order for group consciousness to be present, and the absence of one or more of the three may be illustrative of how political institutions or conditions affect the development of racial group consciousness. For example, if high levels of racial identification are present alongside perceptions of systematic marginalization, yet individuals do not believe collective action is necessary or feasible, then domestic political institutions or national discourses may be acting to inhibit the development or political mobilization of group consciousness. Paschel (2016), for example, characterizes the inhibiting impact that discourses of racial democracy and mestizaje have had on the black collective action in Brazil, and identifies the historic existence of alternative internalized or private strategies, such as marrying whiter, in the place of political action. Similarly, high levels of racial identification absent perceptions of subordination and ascription to political strategies may be indicative of the sort of "ideal" ethnically plural, multi-cultural democracy, such as described in Kymlicka (1995). ${ }^{2}$ The following analysis, therefore, mobilizes this multi-dimensional conceptualization in its comparison of group consciousness, and the following sections consider how structural and historical factors may impact each dimension among blacks in Britain.

\section{BLACK RACIAL IDENTIFICATION IN BRITAIN}

A priori, we might note several compounding institutional, historical, and demographic factors which suggest that black Britons will evince lower levels of racial group identification relative to black Americans. First, blacks in Britain constitute a far smaller percentage of the overall population (3\%) than blacks in the United States (13\%) (Capps, McCabe and Fix 2012; Office of National Statistics 2013). That blacks, and minorities in general, constitute a far smaller share of the population in Britain has a variety of consequences for the history of racial politics in that society. One 
is that black Britons likely did not generate the same levels of racial and political threat that motivated the creation of the institutions, practices, and legislation which historically have made racial identity the ultimate marker of social status and differentiation in the United States, and which formed the principle basis for black American political mobilization and the development of racial group consciousness in the first place. Blalock's (1967) racial threat hypothesis suggests that dominant racial groups are more likely to promote practices designed to keep minority groups politically disempowered and symbolically segregated the more minority groups are perceived to be a challenge or threat to their political hegemony. Consistent with this, a broad literature connects the development and institutionalization of the Black Codes and Jim Crow segregation (Woodward 1955), white mob violence and lynchings (Tolnay and Beck 1995), the development of black ghettos (Wacquant 2008), police use of force against African Americans (Smith and Holmes 2014), and felon disenfranchisement (Behrens, Uggen and Manza 2003) to the size of the black population and white racial threat in the United States. ${ }^{3}$ By imbuing black racial identity with deep historical significance, determining consequences for life outcomes, and structuring the racial composition of social networks, these institutions and practices have and continue to make racial identity a central element of social identity in the United States, and their absence in Britain would suggest, a priori, that blacks have lower levels of racial identity in that national context. $^{4,5}$

The ethnic heterogeneity of the black British population is a second factor that suggests that the centrality of racial identification will be lower in Britain than in the United States. Research conducted on panethnic identification among Asian Americans and Latinos in the United States suggests that ethnic heterogeneity and differences in country of origin inhibit pan-ethnic or racial group consciousnesses among these groups (Junn and Masuoka 2008; Masuoka 2006). Masuoka (2006), for example, found that Asian Americans, the American racial group with the most ethnic heterogeneity in country of origin, have the lowest levels of pan-ethnic identification. Similar research on black immigrants in the United States also suggests that the ability to identify with a specific national origin or ethnic group allows for a symbolic distancing or decentering of racial identity for some, which may also inhibit racial group consciousness among these individuals (Rogers 2006; Waters 1994).

National statistics illuminate the extent of this difference among blacks in the United States and Britain. In 2011, the British Office of National 
Statistics estimated the population of black British Caribbeans and Africans at approximately 595,000 and 1,000,000 people, or 32 and $54 \%$ of the black population, respectively (Office of National Statistics 2013). ${ }^{6}$ Among Britons of Afro-Caribbean ancestry, 37\% report Jamaica as their country of origin; 4-6\% report Trinidad and Tobago, Guyana, or Barbados; and 1-2\% report Grenada, St. Lucia, St. Vincent and the Grenadines, St. Kitt and Nevis, Montserrat, Dominica, or Antigua and Barbuda. Among Britons of African ancestry, 11\% reported Nigeria as their country of birth, 10\% Kenya, 6\% Zimbabwe, and 5\% Ghana or Somalia. In stark contrast, native-born African Americans in the United States constitute an overwhelming majority (91\%) of the black population in the United States (Capps et al. 2012).

Finally, the political approach to racial division and conflict adopted in Britain may have produced important differences in levels of racial identification. The arrival and settlement of West Indian migrants in the 1940s and 1950s was met with race riots and conflict that initiated a political crisis (Garbaye 2005). However, the development and institutionalization of "British multiculturalism" may have had an important limiting effect on racial identification. In the 1960s, and again in the 1970s and 1990s, both Tory and Labor governments addressed racial violence and discrimination with a policy that simultaneously limited black and South Asian immigration to Britain, but also encouraged modes of assimilation into British society that recognized, encouraged, and even celebrated national origin, ethnic and religious differences (Garbaye 2005). Self-consciously trying to avoid the social unrest witnessed in the United States at the time, British multicultural policy both: (1) allowed for the incorporation of black immigrants into the framework of the national community, potentially reducing the value or necessity of black racial identity as an oppositional identity and (2) potentially centralized culture and ethnic national origin (i.e. Jamaica, the West Indies, Ghana, and Nigeria) or religion ( principally Islam) as the basis of incorporation, rather than race (Garbaye 2005; Modood 1988, 2005). Garbaye (2005) has argued that this policy of multiculturalism achieved a level of political consensus among left and right parties as early as the 1970s, suggesting that racial politics of the late 1970s and 1980s in the United States (of race-baiting, subtle racial appeals, attacks on social welfare, etc.) that might also contribute to racial identification and the social subordination of black people was not replicated in Britain to the same degree that it was in the United States (but see Ansell (1998)). 


\section{PERCEPTION OF GROUPS SUBORDINATE STATUS}

The development of racial group consciousness is also dependent on absolute or relative differences in material outcomes, economic status, social standing, and life opportunities based on race; the extent to which these differences have their root in racist, anti-black social-structure; and the extent to which blacks understand or perceive this to be the case (Gurin, Miller and Gurin 1980). In the literature in the United States, no factors seem quite as important to black marginalization and its place in the development of racial group consciousness as segregation, discrimination, and poverty. The profound segregation and socioeconomic marginalization of blacks has not only reinforced the salience and stability of a racial identity, but has allowed for the development of elites, institutions, and counter publics pivotal to the development of racial group consciousness (Bledsoe et al. 1995; Dawson 1994).

An empirical comparison of the material conditions of black Britons and black Americans leads to slightly contradictory or uncertain expectations. On the one hand, the residential segregation of blacks is far more pronounced in the United States than it is in Britain. Several studies suggest that American style ghettos do not exist in Britain and that ethnic minorities in Britain generally experience more spatial assimilation into the majority white society (Simpson 2007). For example, levels of minority segregation in Britain (as measured by ethnic dissimilarity indices) are about half the level of segregation of black Americans (Clark, Putnam, and Fieldhouse 2010). These findings are consistent with other comparative analyses of residential segregation in Brazil (Telles 2004), France (Wacquant 2008), and the United States (Massey and Denton 1993) which have found that residential segregation is higher in the United States.

At the same time, however, there are important similarities in socioeconomic marginalization. While direct comparison of poverty rates is difficult due to differences in purchasing power, government subsidies, and regional differences in cost of living, relative disadvantage among the two groups appear comparable and similar enough to promote the development of racial group consciousness in Britain. Approximately $22 \%$ of African Americans live in poverty, compared to approximately 9\% of white Americans (Fontenot, Semega and Kollar 2018). Similarly, in the fall of 2015, the black unemployment rate of $9 \%$ was more than double the white unemployment rate of $4 \%$. In Britain, poverty (calculated as the share of households that fall below $60 \%$ of median household 
income) was $12 \%$ for whites, compared to $20 \%$ for Afro-Caribbeans and $28 \%$ for black Africans (Fisher and Nandi 2015). About $8 \%$ of white Britons are unemployed, compared to $19 \%$ of black Africans and 20\% of Afro-Caribbeans. Field experiments have also demonstrated that black citizens in both societies experience discrimination. In the United States, Bertrand, Mullainathan and Shafir (2004) demonstrated that all else equal, job applicants with white-sounding names receive $50 \%$ more callbacks than black applicants. These findings are consistent with findings of an "ethnic penalty" for minority groups in Britain (Carmichael and Woods 2000).

This parallel socioeconomic marginalization is mirrored in political marginalization. Historically, black citizens in both the United States and Britain have been underrepresented in local and national legislative bodies, are less likely to have their policy preferences represented in policy, are less likely to be fielded or run as candidates by dominant political parties, and suffer race-based electoral penalties when they do compete for political office (Anwar 2001; Fisher et al. 2015; Kittilson and Tate 2004; Saggar 2004). For example, it was not until 1987, following a sustained political campaign for inclusion, that a black MP was elected (Garbaye 2005). Similarly, black representation in Congress did not surpass 5\% until the 1993 Congressional elections (Kittilson and Tate 2004). Fisher et al. (2015) find that ethnic minority MPs suffer an approximately $4 \%$ penalty (in a 3-party race) compared with white MPs. Similarly, Lewis-Beck, Tien and Nadeau (2010) estimate that racial resentment may have cost Barack Obama 5 percentage points in the 2008 election.

\section{ATTITUDES TOWARDS POLITICAL AND COLLECTIVE ACTION}

The extent to which blacks subscribe to the belief that political actionsuch as voting, civic or community mobilization, or contentious collective action like protests - is needed to rectify their marginalization is the last important constituent element of racial group consciousness. It is not completely clear, however, how these attitudes will differ across black communities. On the one hand, black political mobilization and political intervention played a critical role in the acquisition of political power, antidiscrimination legislation, and representation for black groups in both the United States and Britain. Belief in the importance of black political mobilization and collective action has characterized African American 
political thought since prior to Emancipation (Shelby 2005) and is clearly visible in political struggles ranging from the anti-lynching campaign, the Civil Rights and Black Power Movements, struggles for formal political representation, and against police violence. Race-based political mobilization - in the form of protests, voter and community mobilization, and among black political elites - was similarly central in Britain in struggles against housing discrimination, white violence against blacks, for community control of local services, and for black representation in party politics (Garbaye 2005).

Differences in the duration and political significance of political and collective action in the United States, however, suggests that belief in the necessity of black political mobilization will be stronger in the United States than in Britain. The set of political rights, freedoms, and policies secured by black political mobilization and collective action in the United States is more significant: reductions in lynchings, the end of Jim Crow segregation, and the right to vote for many blacks would not have been accomplished without it. In comparison, black migrants to Britain, as British subjects, were already endowed with voting rights and while black communities did experience white violence (such as in the Notting Hill race riots), such violence did not reach the entrenched systematic level of Jim Crow (Garbaye 2005). More generally collective action among blacks in the United States seems to have struggled more consistently against a more violent or bellicose system of white supremacy and anti-black discrimination. This reality may have also produced a stronger normative valuation of collective action among contemporary black Americans compared with black Britons (Chong 1991; White, Laird and Allen 2014).

\section{HYPOTHESES}

In sum, while some important similarities exist in the factors that would lead to the development of racial group consciousness among black Britons, overall these factors seem more pronounced in the United States. I therefore hypothesize that racial group consciousness will be lower among blacks in Britain and that it will exhibit a weaker relationship with political participation in Britain than in America. More specifically, I hypothesize that:

H1: The share of black Britons who identify strongly with their race will be significantly lower than the share of black Americans who identify strongly with their race 
H2: The share of black Britons who perceive that blacks occupy a subordinate social position will be significantly lower than the share of black Americans who perceive that blacks occupy a subordinate social position

H3: The share of black Britons who support political action to ameliorate black marginalization will be significantly lower than the share of black Americans who support collective political strategies to ameliorate black marginalization

H4: The relationship between these three elements of racial group consciousness and electoral political participation will be weaker in Britain than in the United States.

\section{DATA AND METHODS}

I use the 2001-2003 National Survey of American Life (NSAL) and the 2010 Ethnic Minority British Electoral Survey (EMBES) to explore the relationship between racial group consciousness and political participation among blacks in the United States and Britain respectively. Data for the NSAL was gathered using two methods: face-to-face interviews of households selected from a multi-stage national area probability sample of households with a special supplemental sample of households in areas of higher Afro-Caribbean residential density, and a follow-up self- administered survey. A total of 3,438 respondents completed both aspects of the survey, of whom 2,137 were African American and 695 were Afro-Caribbean. Data from the EMBES was also gathered from households selected from a multi-stage national area probability sample designed specifically to target areas with high concentrations of Afro-Caribbean, black African, Indian, Bangladeshi, and Pakistani Britons. Like the NSAL, data were gathered from face-to-face interviews and a mailed self-administered survey. A total of 2787 respondents completed the survey, of whom 597 identified as black British Caribbean and 524 identified as black British African.

Both data sets contain questions that can be used to measure racial group consciousness and political behavior. Critically, however, the two data sets are independent of one another: they were conducted in different years and using different survey instruments. In an ideal scenario, respondents would be randomly drawn from the United States and Britain and administered the same survey instrument, allowing for a direct, statistical 
comparison of racial group consciousness in the two countries and its effect on political behavior. Unfortunately, such a data set does not currently exist. Nevertheless, the NSAL and the EMBES do contain many of the same questions, so questions and scale measures tapping into similar underlying conceptual dimension or element of racial group consciousness can be constructed and compared. But since the survey instruments do vary, the strategy pursued here is more descriptive, compares the distribution of racial group consciousness, and separately compares its effect on political behavior. In this manner, the data and analysis used here are similar to Masuoka (2006) which used two different surveys to compare the determinants of racial group consciousness within Asian and Hispanic ethnic groups using two different surveys with similar, but not completely overlapping questions.

\section{INDEPENDENT VARIABLES AND OPERATIONALIZATION}

Racial group identification measures the extent to which an individual feels close to their racial group and can be measured using questions that measure either the centrality of racial group identification to an individual's general sense of identity or the extent to which racial identity dominates other forms of identification like national identification (Huddy 2013; Sawyer 2005). In this study, I operationalize Racial Identity with two similarly worded questions from the NSAL and EMBES that ask the respondent whether they identify as black, British or American, or both equally. ${ }^{7}$

Perception of the group's status is the second major component of racial group consciousness. Following Chong and Rogers (2005), I use two measures as proxies for the respondent's perception of the group's subordinate status: experiences with racial discrimination and the extent to which they express discontent with the groups socio-political standing. The NSAL measures the frequency with which respondents were unfairly fired, not hired, denied a promotion, experienced discrimination with the police, discouraged from continuing in education, prevented from moving into a neighborhood, had difficulty in their neighborhood, were denied a loan, or experienced poor service because of their race, skin color, or ancestry. Similarly, the EMBES measures if the respondent experienced discrimination or poor treatment on the street; in a shop, bank, restaurant, or bar; at work or when applying for a job or promotion; when dealing with the police or courts; at school, college or university; when dealing 
with immigration offices or officials; at social gatherings with friends or neighbors; or at family gatherings because of their race, ethnicity, or skin color. In the analysis, I create indicator variables in both data sets which measure whether or not they have experienced any form of discrimination.

Both surveys also contain measures which might proxy for discontent with the group's status or the perception that the group is socially or politically disempowered. Here, however, question-wording between the two surveys diverge significantly, so explicit cross-national comparison of these measures is not possible to the extent that it is with measures of racial identification and experiences with discrimination. Nevertheless, within each survey, responses to these questions are indicative of how blacks view their socio-political position in each country and offer an indication of how the objective socio-political and economic standing of blacks-levels of segregation, poverty, and socio-political marginalization-are perceived by respondents to be both structural and unfair. In the NSAL these questions explore: how much power respondents believe blacks have in American life and politics; their level of satisfaction with race relations in their city or town; whether they believe there has been a substantial improvement in racial discrimination in the past 20 years; whether they believe there will be a significant improvement in racial discrimination 20 years from now; whether they believe whites respect blacks; whether they believe whites view blacks as important contributors to the country; and whether they believe other minorities view blacks as intelligent and competent. In the EMBES, these questions ask: the extent to which respondents believe that the government treats people like them and people from their ethnic group fairly; the extent to which they believe that there is a big gap between what people like them and people from their ethnic group want from life and actually get; whether nonwhites' opportunities are limited by prejudice; how much prejudice exists in Britain; and whether prejudice exists against blacks in Britain. In the descriptive analysis, I present and discuss selected questions which provide a clear characterization of cross-national patterns in perceptions of black marginalization. In the regression analysis, I sum responses to these questions in both the NSAL and EMBES to produce a scale measure called Discontent with Status in each survey (the Cronbach's value for this scale in the NSAL is .67 and is .75 in the EMBES).

The final conceptual element of racial group consciousness is a respondent's willingness to engage in forms of political behavior (especially collective action) that would remedy black marginalization. 
Unfortunately, neither the NSAL and EMBES include questions that explicitly measure this attitude. Both surveys do, however, contain questions that gauge a respondent's endorsement for different political or cultural strategies that might improve the conditions of blacks. As Chong and Rogers (2005), Lee (2008), and Paschel (2016) note, conscious groups can endorse or pursue different political strategies, depending on context, and these different approaches might differ in their association with different forms of political participation. Using variables from both surveys, I construct two measures, called Government Intervention and Cultural Distinction, which reflect different approaches to black empowerment utilized by blacks in both the United States and Britain. Historically, some blacks in both nations have endorsed the position that the government or other political institutions should adopt proactive policies to improve the condition of blacks, such as affirmative action or minority shortlists. At the same time, blacks in both countries have endorsed more radical "separatist" political programs that are skeptical of strategies of integration and held that blacks ought not to completely assimilate into the dominant society but remain (at least culturally) separate or distinct (Shelby 2005; Garbaye 2005; Andrews 2016).

To proxy for support for these two different types of political programs in the NSAL, I create a scale, Government Intervention, from questions that measure respondent support for government intervention on behalf of blacks, including whether or not the government should make every effort to improve the social and economic position of blacks in the United States, give reparations, and create specialty districts for minorities $(\alpha=.71)$. The second scale, Cultural Distinction, is constructed from questions that ask whether or not the respondent believes in intra-racial marriage, whether or not blacks should always vote for black candidates, form their own political party, shop at black-owned stores, and give their kids African names $(\alpha=0.8)$.

In the EMBES, only a small subsample of respondents was asked a full set of questions that could proxy for these attitudes. In the descriptive analysis that follows, I present the survey results from questions that asked this subset of black Britons whether or not minorities should be given preferences in hiring to correct for past discrimination, whether the government should give special treatment to blacks, and whether the government must protect minority interests, and take these questions as indicative of black British support for Government Intervention. Similarly, from this subset of survey respondents I display the descriptive results of questions which probe the importance of black integration and mixing into the dominant 
society, perceptions of cultural conflict between the respondent's culture and the dominant society, and the value of highlighting cultural difference, and take these questions as indicative of Cultural Distinction. In the regression analysis, however, I proxy for Government Intervention with a question which asked survey respondents the extent to which they believe racial minorities should be given preferences in hiring to make up for past discrimination, and I proxy for Cultural Distinction with a question that queried respondents the extent to which they agree that their group should maintain its own values, beliefs, and traditions. ${ }^{8}$

Finally, and for the regression analysis, I control for a series of factors measured in both the NSAL and EMBES that may independently affect an individual's likelihood of voting. Specifically, I include variables to control for education, age, income, gender, marital status, strength of partisanship, and membership in civic associations, which extant studies have found affect voter participation (Brady, Verba, and Schlozman 1995; Heath et al. 2013; Smith 2013). ${ }^{9}$

\section{DEPENDENT VARIABLES}

Extant studies of racial group consciousness have explored the degree to which it impacts voter turnout, membership in community organizations, and participation in contentious politics like protesting and boycotting (Chong and Rogers 2005; Miller et al. 1981). This study focuses specifically on the impact of racial group consciousness on black voter turnout, which was important to the success of black movements in the United States and Britain. ${ }^{10}$ In the regression analysis, I use questions asked in both data sets which measure self-reported voter turnout, which as a proxy for political participation, has the additional advantage of being a relatively comparable and meaningful in both national contexts.

\section{DESCRIPTIVE RESULTS}

In Table 1, I display the descriptive results of racial group identification in the two countries. The results suggest a striking similarity in the distribution of racial identification versus national identification among black residents in both countries, contrary to the expectations presented in Hypothesis 1. Low and comparable shares of black respondents, $7 \%$ in the United States and 3\% in Britain, said their sense of national identification was more important than their racial identification, while similarly 
Table 1. Racial versus national identification in the United States and Britain

\begin{tabular}{|c|c|c|c|c|c|}
\hline & $\begin{array}{l}\text { Black } \\
\text { Americans }\end{array}$ & $\begin{array}{l}\text { Black } \\
\text { Britons }\end{array}$ & $\begin{array}{l}2^{\text {nd }} \\
\text { generation } \\
+(\text { Britain })\end{array}$ & $\begin{array}{l}\text { Afro-Caribbean } \\
\text { (Britain) }\end{array}$ & $\begin{array}{l}\text { African } \\
\text { (Britain) }\end{array}$ \\
\hline British/American & 7 & 3 & 4 & 4 & 2 \\
\hline $\begin{array}{l}\text { More British/American } \\
\text { than Black }\end{array}$ & - & 7 & 9 & 8 & 6 \\
\hline Both equally & 71 & 46 & 53 & 51 & 42 \\
\hline $\begin{array}{l}\text { More Black than } \\
\text { British/American }\end{array}$ & - & 26 & 25 & 26 & 26 \\
\hline Black & 22 & 19 & 10 & 13 & 25 \\
\hline $\mathrm{N}$ & 2,693 & 1,075 & 394 & 576 & 494 \\
\hline
\end{tabular}

Source: National Survey of American Life, 2001-2003 and British Election Study, Ethnic Minority Survey 2010.

high and comparable shares, $22 \%$ in the United States and $19 \%$ in Britain, felt that their racial identity is more important than their national identity.

Importantly, Table 1 shows that the results in Britain are not being driven entirely by first-generation immigrants, for whom national identification may be particularly weak, or by any single ethnic group. Column 3 shows racial identification for second and later generation black Britons. Though black Britons of these generations are less likely to report that it is more important to be black (and more likely to report both equally), the similar pattern between the United States and Britain largely holds. Columns 4 and 5 show differences by ethnicity and again the similarity in the distribution of responses largely holds. Interestingly, African Britons report the highest levels of racial identification of all groups (including black Americans) even though as a group they are more recent immigrants than Afro-Caribbeans.

In Table 2, I display descriptive results of experiences with discrimination. The results again show a similarity in the racial experiences of black citizens in the United States and Britain, contrary to Hypothesis 2. Approximately $38 \%$ of black Britons have experienced any racism because of their skin color, race, or ancestry in the last 5 years compared with the $40 \%$ of black Americans report experiencing discrimination in their entire life. $^{11}$

In Table 3, I compare the extent to which black Americans and black Britons are discontent with their group's socio-political standing. While 
Table 2. Experiences with discrimination in the United States and Britain

\begin{tabular}{lcc}
\hline & Black Americans & Black Britons \\
\hline Never experienced & 60 & 62 \\
Have experienced & 40 & 38 \\
Rarely & - & 11 \\
Sometimes & - & 22 \\
Often & - & 6 \\
$N$ & 2,832 & 1,219 \\
\hline
\end{tabular}

Source: National Survey of American Life, 2001-2003 and British Election Study, Ethnic Minority Survey 2010.

some results suggest cross-national parity in perceptions of black marginalization - such that blacks in both countries appear neither optimistic nor pessimistic in regard to black social standing - the overall results suggest that blacks in Britain are somewhat less likely to perceive the social system as fundamentally antagonistic to blacks. For example, 52\% of respondents to the NSAL believe that blacks have a great deal or some power in American politics and life, compared to $48 \%$ of black Americans who believe that blacks have only a little or no power at all. And while 54\% of NSAL respondents believe that the election of blacks to high political office has helped the cause of blacks, $46 \%$ of respondents do not. Similarly, nearly equal shares of black Britons believe that the government treats members of their ethnic group fairly (38\%) compared to those who do not (33\%). At the same time, somewhat large majorities of black Britons do not identify blacks as a group experiencing prejudice in British society ( $58 \%$ compared to $42 \%$ ), disagreed with the notion that there is a gap between what members of their ethnic group expect and receive out of life (67\% compared to $14 \%$ ), and disagreed that prejudice limits opportunities in British society (46\% compared to 24\%). Overall, it appears that black Britons are less pessimistic about their status than black Americans, consistent with Hypothesis 2.

Finally, Table 4 shows how respondents view different political programs as a means to address these issues. Overall, results from Table 4 suggest that black Americans strongly support affirmative government programs while disavowing strong cultural separatism/distinction. Blacks in Britain do not consistently evince as large degree of support for positive government intervention on the behalf of blacks and are moderately supportive of notions of assimilation, consistent with Hypothesis 3. The smaller degree of support for government intervention expressed by 
Table 3. Perception of subordinate group status in the United States and Britain

\begin{tabular}{|c|c|c|c|}
\hline & $\begin{array}{l}\text { Strongly agree/ } \\
\text { agree/yes }\end{array}$ & Neither & $\begin{array}{l}\text { Strongly disagree/ } \\
\text { disagree/no }\end{array}$ \\
\hline \multicolumn{4}{|l|}{ Black British attitudes } \\
\hline $\begin{array}{l}\text { Government treats my ethnic group } \\
\text { fairly }\end{array}$ & 38 & 28 & 34 \\
\hline Government treats people like me fairly & 45 & 26 & 30 \\
\hline $\begin{array}{l}\text { Nonwhites' chances limited by } \\
\text { prejudice }\end{array}$ & 24 & 19 & 46 \\
\hline Gap in life expectations \& reality: & 14 & 20 & 67 \\
\hline Do Blacks experience discrimination? & 42 & - & 58 \\
\hline Black American Attitudes & $\begin{array}{l}\text { A great deal/ } \\
\text { some }\end{array}$ & & A little/none at all \\
\hline \multirow{2}{*}{$\begin{array}{l}\text { Amount of Black political power in } \\
\text { United States }\end{array}$} & 52 & & 48 \\
\hline & $\begin{array}{l}\text { Very/somewhat } \\
\text { satisfied }\end{array}$ & & $\begin{array}{l}\text { Very/somewhat } \\
\text { dissatisfied }\end{array}$ \\
\hline \multirow{2}{*}{$\begin{array}{l}\text { Satisfied with race relations in } \\
\text { town/city? }\end{array}$} & 63 & & 37 \\
\hline & Helped Blacks & & $\begin{array}{l}\text { Made no } \\
\text { difference/hurt } \\
\text { Blacks }\end{array}$ \\
\hline \multirow[t]{2}{*}{ Election of Blacks to high office } & 54 & & 46 \\
\hline & Positively & & Negatively \\
\hline $\begin{array}{l}\text { How do other racial groups regard } \\
\text { Blacks }\end{array}$ & 30 & & 70 \\
\hline
\end{tabular}

Source: National Survey of American Life, 2001-2003 $(n=2832)$ and British Election Study, Ethnic Minority Survey $2010(n=1220)$.

black Britons is consistent with expectations: collective action and demands for positive government action for blacks has played a somewhat smaller role in black British political history compared with black American political history and may be less normatively entrenched.

Table 4 suggests that black American respondents overwhelmingly support interventions the government could take to improve the condition of blacks and show little support for cultural black separatism. Large majorities agree or strongly agree that the U.S. government should pay blacks reparations for slavery $(64 \%)$, do everything in its power to improve the condition of blacks (81\%), and create special districts to ensure the election of black political candidates (69\%). Few offered support for black distinction or separatism: 68\% disagreed (or strongly disagreed) that blacks should only shop at black controlled stores, $72 \%$ disagreed that blacks should only vote for black candidates, $68 \%$ disagreed that blacks should 
Table 4. Attitudes concerning political action in the United States and Britain

\begin{tabular}{|c|c|c|c|c|c|}
\hline & $\begin{array}{l}\text { Strongly } \\
\text { disagree }\end{array}$ & Disagree & Neither & Agree & $\begin{array}{l}\text { Strongly } \\
\text { agree }\end{array}$ \\
\hline \multicolumn{6}{|l|}{ Black British Attitudes } \\
\hline Blacks need to integrate to succeed & 6 & 23 & 29 & 27 & 15 \\
\hline $\begin{array}{l}\text { Blacks should mix and integrate with } \\
\text { whites }^{\mathrm{a}}\end{array}$ & 0 & 3 & 21 & 52 & 25 \\
\hline $\begin{array}{l}\text { Conflict with British and my culture is } \\
\text { rare }^{\mathrm{a}}\end{array}$ & 3 & 18 & 27 & 41 & 11 \\
\hline $\begin{array}{l}\text { Minorities shouldn't highlight } \\
\text { differences }^{\mathrm{a}}\end{array}$ & 4 & 13 & 30 & 33 & 19 \\
\hline Affirmative action or priority in hiring & 13 & 40 & 19 & 22 & 7 \\
\hline $\begin{array}{l}\text { Minorities should be given special } \\
\text { treatment }^{\mathrm{a}}\end{array}$ & 12 & 44 & 30 & 10 & 5 \\
\hline $\begin{array}{l}\text { Government must protect minority } \\
\text { interests }^{\mathrm{a}}\end{array}$ & 1 & 6 & 26 & 45 & 22 \\
\hline \multicolumn{6}{|l|}{ Black American Attitudes } \\
\hline Government should pay reparations & 20 & 17 & - & 26 & 38 \\
\hline $\begin{array}{l}\text { Government should improve Blacks" } \\
\text { conditions }\end{array}$ & 6 & 12 & - & 39 & 43 \\
\hline Create majority Black political districts & 10 & 21 & - & 44 & 25 \\
\hline $\begin{array}{l}\text { Blacks should only shop at Blacks owned } \\
\text { stores }\end{array}$ & 39 & 30 & - & 23 & 8 \\
\hline $\begin{array}{l}\text { Blacks should only vote for Black } \\
\text { candidates }\end{array}$ & 40 & 32 & - & 13 & 7 \\
\hline $\begin{array}{l}\text { Blacks should give children African } \\
\text { names }\end{array}$ & 43 & 26 & - & 7 & 3 \\
\hline $\begin{array}{l}\text { Blacks should form their own political } \\
\text { party }\end{array}$ & 35 & 27 & - & 17 & 10 \\
\hline
\end{tabular}

Source: National Survey of American Life, 2001-2003 ( $n=2832)$ and British Election Study, Ethnic Minority Survey $2010(n=1220)$.

${ }^{\text {a }}$ Question asked of a subset $(n=433)$ of EMBES.

give their children African names, and 62\% disagreed that blacks should form their own political party.

Table 4 also shows black British attitudes towards government programs. There is demonstrably less support for positive government intervention for actions such as promoting the hiring of blacks to rectify the effects of discrimination (28\% agreed or strongly agreed) or giving minorities special treatment (14\% agreed or strongly agreed). At the same time, however, 67\% of EMBES respondents did believe that the government should protect the interest of minorities, so the evidence here is slightly mixed. Respondents to the EMBES also seem to largely support the 
idea of cultural assimilation, with majorities agreeing that blacks should mix with the larger population (77\% vs 3\%), that cultural conflict with the majority group is rare (52\% vs $21 \%$ ), and that ethnic or racial minorities should not highlight cultural differences ( 52 vs 17\%). A plurality also agreed that minorities needed to integrate to be successful (42 vs 29\%). Altogether the results suggest that both blacks in the United States and Britain support the notion that blacks need to integrate, mix, or participate in the larger society, but blacks in the United States appear more supportive of the notion that government should intervene positively on their behalf than blacks in Britain.

\section{REGRESSION RESULTS}

The descriptive results above suggest important similarities and differences in racial group consciousness between blacks in the United States and Britain. Afro-descendant individuals in both societies report high levels of racial identification, experiences with discrimination, and belief that blacks ought to assimilate, integrate, or engage in the larger society. At the same time, blacks in Briton appear to be less likely to believe that blacks occupy a socially marginalized position (though not dramatically so) and less likely to support positive government intervention or strategies targeting blacks. It is not yet clear, however, the extent to which these elements of racial group consciousness predict political participation and how this varies across national context. As noted, extant studies in the literature utilizing the multi-dimensional measure have found a positive association between political participation and both racial/pan-ethnic identification and perceptions of group marginalization-perception of discrimination and subscription to beliefs concerning collective action were not significant predictors in Chong and Roger's (2005) study. We would expect this pattern to hold among black respondents to the NSAL but hypothesized that the relationship between group consciousness attitudes and political action among black Britons would be weaker or nonexistent.

Tables 5 and 6 present the result of logistic regressions testing the relationship between group consciousness and voter turnout among black Americans and black Britons respectively. In addition to reporting how changes in each covariate affects the odds of turnout, each table reports the first difference value associated with each covariate. These values report changes in the predicted probability of voting when the associated covariate is switched from the minimum value it obtains in the data set to 
Table 5. Correlates of Black American political participation

\begin{tabular}{|c|c|c|}
\hline & Voting & $\Delta$ \\
\hline Racial identity & $0.51^{* *}(0.33,0.77)$ & $-0.13^{* * *}$ \\
\hline Personal discrimination & $0.84(0.68,1.05)$ & -0.03 \\
\hline Discontent with status & $2.06 *(1.09,3.90)$ & $0.14^{*}$ \\
\hline Government intervention & $1.1(0.65,1.84)$ & 0.02 \\
\hline Cultural distinction & $1.64(0.99,2.70)$ & 0.09 \\
\hline Education & 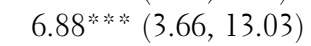 & 0.38 头䧇 \\
\hline Age & $1.04^{\text {的称 }}(1.03,1.04)$ & 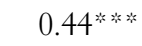 \\
\hline Income (Log) & 1.30 等的 $(1.14,1.49)$ & 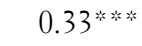 \\
\hline Gender & $0.79 *(0.63,0.98)$ & $-0.05^{*}$ \\
\hline Married & $0.83(0.66,1.05)$ & -0.04 \\
\hline Club or civic association & $1.47 *(1.05,2.08)$ & $0.07^{*}$ \\
\hline Partisanship & 3.32 等的 $(2.53,4.37)$ & 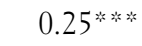 \\
\hline Constant & 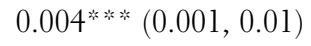 & - \\
\hline Observations & 1,903 & \\
\hline Log likelihood & -914.73 & \\
\hline $\mathrm{AIC}$ & 2175.7 & \\
\hline
\end{tabular}

Note: ${ }^{*} p<0.05 ;{ }^{* * *} p<0.01 ;{ }^{* * * *} p<0.001$.

the maximum value it obtains in the data set. For example, the first difference value associated with Racial Identity estimates how the probability of voting would change if an individual shifted from believing it is more important to identify as American to believing it is more important to identify as black. $^{12}$

The results of the regression analysis present evidence that generally supports Hypotheses 4, the expectation that the relationship between racial group consciousness and voter turnout will be stronger in the United States, but with one important exception: the results suggest that racial identification exerts a negative effect on voter turnout among blacks in both societies. Table 5 presents the logistic regressions results from the NSAL. The results suggest a strong and negative association between racial identification on voter turnout. First differences suggest that movement across the range of possible values, from identifying as "American" to "Black", is associated with a $13 \%$ decline in the probability of voting. While personal experiences with discrimination are not significantly related to the likelihood of voting, black Americans who are more discontented with the status of blacks in America are also more likely to vote. Across the range of values of the discontent scale, a switch from the minimum to the maximum possible value of Discontent with 
Table 6. Correlates of Black British political participation

\begin{tabular}{|c|c|c|}
\hline & Voting & $\Delta$ \\
\hline Racial identity & $0.82 * *(0.72,0.93)$ & $-0.14^{\text {*** }}$ \\
\hline Personal discrimination & $1.11(0.70,1.76)$ & 0.02 \\
\hline Discontent with status & $1.21(0.21,7.19)$ & 0.03 \\
\hline Government intervention & $1.49(0.70,3.22)$ & 0.07 \\
\hline Cultural distinction & $1.58(0.39,6.28)$ & 0.08 \\
\hline Education & $1.1(0.90,1.34)$ & 0.05 \\
\hline Age & 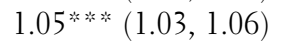 & 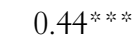 \\
\hline Income & $1.09 *(1.02,1.16)$ & $0.17^{*}$ \\
\hline Gender & $0.75(0.49,1.15)$ & -0.05 \\
\hline Married & $1.84 *(1.17,2.94)$ & $0.1^{* * x^{2}}$ \\
\hline Club or civic association & $1.74 *(1.13,2.69)$ & $0.09 *$ \\
\hline Partisanship & 2.18 皮的 $(1.69,2.83)$ & 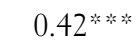 \\
\hline Constant & $0.03^{\text {米和 }}(0.004,0.19)$ & - \\
\hline Observations & 539 & \\
\hline Log likelihood & -272.89 & \\
\hline $\mathrm{AIC}$ & 571.78 & \\
\hline
\end{tabular}

Note: ${ }^{*} p<0.05 ;{ }^{* * *} p<0.01 ; * * * p<0.001$.

Status is associated with a $14 \%$ increase in the probability of voting. Somewhat surprisingly (yet nevertheless consistent with Chong and Rogers (2005)), the regression results presented in Table 5 find no relationship between support for political action and voter turnout: neither support for pro-active government intervention nor endorsement of cultural distinction were significantly associated with voter turnout.

Beyond these indicators of racial group consciousness, the control variables largely behaved as expected. Higher levels of education, older age, more income, higher levels of partisanship, and membership in a community or civic association was associated with an increase in turnout. Gender (female) was associated with a decrease in turnout, while no relationship was identified between marital status and turnout.

Table 6 presents logistic regression results from the EMBES. As with black respondents to the NSAL, strong racial versus national identification was associated with a moderate reduction in the probability of voting - movement across the range from national to racial identification was associated with a $14 \%$ reduction in the likelihood of voting. Unlike in the NSAL, however, discontent with status was not significantly associated with the turnout. And as with the NSAL, neither support for government intervention nor cultural separatism was associated with voter turnout. 
Control variables again largely behave as expected, though several expected controls do not exhibit a relationship with voting. Consistent with expectations, marital status, elder age, membership in a civic association, partisanship, and income were positively associated with voter turnout. Contrary to expectations, neither education nor gender affected individual propensity to vote.

\section{DISCUSSION AND CONCLUSION}

How does the prevalence and political significance of racial group consciousness compare among black groups in the United States and Britain? Using a multi-dimensional operationalization of group consciousness, this study compared racial group consciousness among blacks in the two societies and its relationship with political participation in the form of voter turnout.

Overall, the results suggest that while elements of racial group consciousness exist among blacks in both the United States and Britain attitudes constitutive of racial group consciousness are overall more prevalent and politically impactful in the United States. For example, the analysis uncovered unexpected similarities in the extent to which blacks in both countries identified principally as "black" rather than British or American, despite significant ethnic heterogeneity in the black British population, lower levels of residential and social segregation in Britain, and a less acrimonious and violent domestic racial history. Tentatively, these results could speak to the impact that other factors-particularly the experience of racial discrimination (which were reported with similar frequencies among blacks in the two societies) - and their ability to produce high levels of racial identification despite different ethnic backgrounds. Like Paschel's (2016) work on black social movements in Brazil and Colombia, the results suggest that politically meaningful and salient modes of racial identification can emerge in contexts that lack the unique racial history and institutions of the United States. Put alternatively, the fact that Britain did not institute laws and social practices like Jim Crow may not matter for explaining the strength of racial identification in contemporary Britain.

At the same time, however, and consistent with expectations, while blacks in neither society are fully satisfied with the status and political power that they have, blacks in Britain appear less discontent or likely to view blacks as occupying a fundamentally marginalized structural 
position. Cross-national differences in attitudes towards collective action are somewhat more pronounced: while blacks in both societies support integration and social mixing, blacks in the United States are stronger supporters of affirmative action and government practices to improve the status of blacks.

In addition to these descriptive results, regression analysis point to interesting similarities and differences as well. Racial group identification displayed a very similar, negative relationship with the likelihood of turning out to vote in both countries. This relationship was also unexpected and is inconsistent with literature that has frequently found group consciousness to be positively associated with voter turnout. The difference identified here likely lies in question-wording, specifically the use of question-wording that juxtaposed racial identification against national identification, which has not been consistently used in prior studies (see for example Chong and Rogers 2005). Substantively, however, the finding that similar shares of blacks in the two countries identified primarily with their race rather than their nation, and that this attitude is associated with lower levels of electoral participation, is significant and suggests greater similarity in-group attachment among blacks in the United States and Britain that may be appreciated by the extant literature.

Similarly, attitudes towards different strategies of collective action seem largely unrelated to voter turnout in both countries. Differences in discontent with group status and its relationship to voter turnout appear to be the most interesting observed differences between the two groups. As was made clear in the descriptive analysis, blacks in both societies are at least somewhat discontent with the status of blacks in their societies, yet these attitudes are only related to political participation in the United States. Rogers' (2006) analysis of racial group consciousness among Afro-Caribbean immigrants in New York offers a potential explanation. Rogers (2006) argues both that civic associations, social networks, and black "counter-publics" provide the material and discursive space for consciousness-raising ideas to be transmitted, and that the political opportunity structure of local and even national politics may affect the relationship between the constituent elements of consciousness and political participation. It may be the case the discontent with the status of blacks in Britain is not afforded the same central role in discourse, that heterogeneity in national origin groups affects racial group consciousness through its effect on black counter-publics in Britain, or that the political system in Britain is less open to candidates who might attempt to capitalize 
on black discontent. Explicit comparison along these lines might prove a promising line of research for further studies.

The analysis in this study was hampered by important constraints. Principally, despite similarities in the wording of some questions across the two surveys, question-wording in other measures was different, limiting the strength of the conclusions that can be drawn from the analysis. Furthermore, the single question measures designed to proxy for support for government intervention and cultural distinction from the EMBES are likely not as reliable as the multi-question scales built from the NSAL. The data also limited the forms of political participation that could be considered. Extant work has explored the impact of racial group consciousness on a diverse range of forms of political participation, from electoral participation to participation in contentious forms of collective action. Future work may consider exploring the impact of consciousness on these behaviors and others such as online political engagement or candidate choice (Martin 2016).

Another limitation is the associational nature of the analysis and the inability of the analysis to compare potential causal pathways. The data set does not contain sufficiently similar question wording such that a robust set of potential mediating or moderating relationships, such as those explored in Fisher et al. (2015), could be adequately compared among blacks in both national contexts. Future data collection efforts may want to consider potential pathways and moderating effects in the national contexts analyzed.

\section{NOTES}

1. Throughout the paper, I refer to individuals of African descent in the United States and in other countries as black, noting however, important variation in this practice, debate over the application of concepts generated from the study of race in the United States to other national contexts, and crossnational and historical differences in which ethnicities were racialized as "black" (Bourdieu and Wacquant 1999; Modood 1988; Paschel 2016; Sawyer 2005).

2. Of course, lack of a perception of black marginalization may not coincide with empirical reality, in which case national discourses of racial democracy and "exclusionary-inclusion" may again be at work (Paschel 2016; Sawyer 2005; Sawyer, Pena, Sidanius 2004).

3. This is not to suggest the absence of racist or marginalizing practices and institutions, white racial threat, or black racial identity in Britain, however. See, for example, Garbaye (2005), Modood (2005), and Modood (1998).

4. As Acharya et al. (2016) note, these institutions and practices can have long term effects on racial attitudes and preferences, long since they have disappeared.

5. For example, Bledsoe et al. (1995), who describe racial segregation as the "structural linchpin" of American race relations, found a positive relationship between racial segregation and racial solidarity, possibly through segregation's effect on determining the racial composition of black social networks. 
6. A remaining 280,000 blacks or $15 \%$ do not identify ethnically. An additional 427,000 reported being mixed white and Caribbean.

7. In a slight difference, respondents to the EMBES were allowed intermediate or mixed modes of identification: "More Black than British" and "More British than Black". Exact question wording and variable coding for all variables can be found in the Appendix.

8. This reliance on single survey questions in these two instances is non-ideal, but unfortunately the entire sample was not asked questions that could be used to construct a more robust scale measure as in the NSAL

9. These control variables are often measured differently in the two surveys. See the Appendix for exact question wording and control variable construction.

10. In the ideal measurement scenario, both the NSAL and the EMBES would ask questions about a broader range of political behaviors, such as contacting a political official, donating to political campaign, being a member a black political organization or group, and participating in a protesting or demonstrating. Unfortunately, a question about voting was the only question about political participation asked in both surveys.

11. Question-wording here somewhat undermines a straight forward interpretation of the results. That respondents to the NSAL report more discrimination than respondents to the EMBES may be a result of the longer time scale of the NSAL's question wording. The reported difference between the two nations is small however, despite significant differences in time scale. And, if anything, the results suggest that if questions were comparable, such that the NSAL asked about experiences with discrimination in the past 5 years rather than the entire lifetime, the results might show that reports of discrimination were higher in Britain than in the United States (under the assumption that experiences with discrimination have declined over time in the United States).

12. Rather than holding the values of other covariates at their means, I estimate how such a switch would affect the predicted probability of voting for each individual entry in the actual data set (keeping all other values at their actual values in the data set) and then take the average of the change across all observations.

\title{
SUPPLEMENTARY MATERIAL
}

\author{
The supplementary material for this article can be found at https://doi.org/ \\ $10.1017 /$ rep.2018.28
}

\section{REFERENCES}

Acharya, Avidit, Matthew Blackwell, and Maya Sen. 2016. “The Political Legacy of American Slavery." The Journal of Politics 78 (3): 621-41.

Andrews, Kehinde. 2016. "The Problem of Political Blackness: Lessons from the Black Supplementary School Movement." Ethnic and Racial Studies 39 (11): 2060-78.

Ansell, Amy E. 1998. New Right, New Racism: Race and Reaction in the United States and Britain. New York: New York University Press.

Anwar, Muhammad. 2001. "The Participation of Ethnic Minorities in British Politics." Journal of Ethnic and Migration Studies 27 (3): 533-49.

Austin, Sharon D. Wright, Richard T. Middleton, and Rachel Yon. 2012. "The Effect of Racial Group Consciousness on the Political Participation of African Americans and Black Ethnics in Miami-Dade County, Florida." Political Research Quarterly 65 (3): 629_41.

Behrens, Angela, Christopher Uggen, and Jeff Manza. 2003. "Ballot Manipulation and the 'Menace of Negro Domination': Racial Threat and Felon Disenfranchisement in the United States, 1850-20021." American Journal of Sociology 109 (3): 559-605. 
Bertrand, Marianne, Sendhil Mullainathan, and Eldar Shafir. 2006. "Behavioral Economics and Marketing in Aid of Decision Making Among the Poor." Journal of Public Policy \& Marketing 25 (1): 8-23.

Blalock, Hubert M. 1967. Toward a Theory of Minority-Group Relations. New York: John Wiley \& Sons.

Bledsoe, Timothy, Susan Welch, Lee Sigelman, and Michael Combs. 1995. "Residential Context and Racial Solidarity among African Americans." American Journal of Political Science 39 (2): 434-58.

Bourdieu, Pierre, and Loïc Wacquant. 1999. "On the Cunning of Imperialist Reason." Theory, Culture \& Society 16 (1): 41-58.

Brady, Henry E., Sidney Verba, and Kay L. Schlozman. 1995. "Beyond SES: A Resource Model of Political Participation." American Political Science Review 89 (2): 271-94.

Capers, Juree K., and Candis Watts Smith. 2016. "Straddling Identities: Identity Cross-Pressures on Black Immigrants' Policy Preferences." Politics, Groups, and Identities 4 (3): 393-424.

Capps, Randy, Kristen McCabe, and Michael Fix. 2012. Diverse Streams: African Migration to the United States. Washington, DC: Migration Policy Institute. http://www.ww. migrationinformation.com/sites/default/files/publications/CBI-AfricanMigration.pdf (May 21, 2016).

Carmichael, Fiona, and Robert Woods. 2000. "Ethnic Penalties in Unemployment and Occupational Attainment: Evidence for Britain.” International Review of Applied Economics 14 (1): 71-98.

Chong, Dennis. 1991. Collective Action and the Civil Rights Movement. Chicago: University of Chicago Press.

Chong, Dennis, and Reuel Rogers. 2005. "Racial Solidarity and Political Participation." Political Behavior 27 (4): 347-74.

Clark, Tom, Robert D. Putnam, and Edward Fieldhouse. 2010. The Age of Obama: The Changing Place of Minorities in British and American Society. New York: Oxford University Press.

Dawson, Michael C. 1994. Behind the Mule-Race and Class in African-American Politics. Princeton: Princeton University Press.

Fisher, Paul, and Alita Nandi. 2015. Poverty Across Ethnic Groups Through Recession and Austerity. York: Joseph Roundtree Foundation.

Fisher, Stephen D., Anthony F. Heath, David Sanders, and Maria Sobolewska. 2015. "Candidate Ethnicity and Vote Choice in Britain." British Journal of Political Science 45 (4): 883-905.

Fontenot, Kayla, Jessica Semega, and Melissa Kollar. 2018. Income and Poverty in the United States: 2017. Washington, DC: United States Census Bureau.

Garbaye, Romain. 2005. 23 Getting into Local Power: The Politics of Ethnic Minorities in British and French Cities. Oxford: Blackwell Publishing.

Gay, Claudine, Jennifer Hochschild, and Ariel White. 2016. "Americans' Belief in Linked Fate: Does the Measure Capture the Concept?” Journal of Race, Ethnicity and Politics 1 (1): 117-44.

Goldberg, David T. 2002. The Racial State. Hoboken: Wiley-Blackwell.

Greer, Christina M. 2013. Black Ethnics: Race, Immigration, and the Pursuit of the American Dream. New York: Oxford University Press.

Gurin, Patricia, Arthur H. Miller, and Gerald Gurin. 1980. "Stratum Identification and Consciousness." Social Psychology Quarterly: 30-47.

Hanchard, Michael. 2003. "Acts of Misrecognition: Transnational Black Politics, Anti-imperialism and the Ethnocentrisms of Pierre Bourdieu and Loïc Wacquant." Theory, Culture \& Society 20 (4): 5-29. 
Hanchard, M., and Erin A Chung. 2004. "From Race Relations to Comparative Racial Politics: A Survey of Cross-National Scholarship on Race in the Social Sciences." Du Bois Review: Social Science Research on Race 1 (2): 319-43.

Heath, Anthony F., Stephen D. Fisher, Gemma Rosenblatt, David Sanders, and Maria Sobolewska. 2013. The Political Integration of Ethnic Minorities in Britain. Oxford: Oxford University Press.

Huddy, Leonie. 2013. "From Group Identity to Political Cohesion and Commitment." In Oxford Handbook of Political Psychology, eds. Sears, David O., Leonie Huddy, and Robert Jervis. New York: Oxford University Press, pp. 511-58.

Hutchings, Vincent L., and Nicholas A. Valentino. 2004. "The Centrality of Race in American Politics." Annual Review of Political Science 7: 383-408.

Junn, Jane, and Natalie Masuoka. 2008. "Asian American Identity: Shared Racial Status and Political Context." Perspectives on Politics 6 (4): 729-40.

Kittilson, Miki C., and Katherine Tate. 2004. Political Parties, Minorities and Elected Office: Comparing Opportunities for Inclusion in the U.S. and Britain. Center for the Study of Democracy. http://escholarship.org/uc/item/9j40klm0 (April 21, 2016).

Kymlicka, Will. 1995. Multicultural Citizenship: A Liberal Theory of Minority Rights. Oxford: Clarendon Press.

Lee, Taeku. 2008. "Race, Immigration, and the Identity-to-Politics Link." Annual Review of Political Science 11: 457-78.

Lewis-Beck, Michael S., Charles Tien, and Richard Nadeau. 2010. “Obama's Missed Landslide: A Racial Cost?” PS: Political Science \& Politics 43 (1): 69-76.

Martin, Nicole S. 2016. "Do Ethnic Minority Candidates Mobilise Ethnic Minority Voters? Evidence from the 2010 UK General Election." Parliamentary Affairs 69 (1): 159-80.

Massey, Douglas S., and Nancy A. Denton. 1993. American Apartheid: Segregation and the Making of the Underclass. Cambridge: Harvard University Press.

Masuoka, Natalie. 2006. "Together They Become One: Examining the Predictors of Panethnic Group Consciousness Among Asian Americans and Latinos*." Social Science Quarterly 87 (5): 993-1011.

McClain, Paula D., Jessica D. Johnson Carew, Eugene Walton Jr, and Candis S. Watts. 2009. "Group Membership, Group Identity, and Group Consciousness: Measures of Racial Identity in American Politics?" Annual Review of Political Science 12: 471-85.

Miller, Arthur H., Patricia Gurin, Gerald Gurin, and Oksana Malanchuk. 1981. "Group Consciousness and Political Participation." American Journal of Political Science 23 (3): 494-511.

Modood, Tariq. 1988. “Black', Racial Equality and Asian Identity." Journal of Ethnic and Migration Studies 14 (3): 397-404.

Modood, Tariq. 1998. "Ethnic Diversity and Racial Disadvantage in Employment." In Race Relations in Britain: A Developing Agenda, eds. Blackstone, Tessa, Bhikhu Parekh, and Peter Sanders. London: Routledge, pp. 53-73.

Modood, Tariq. 2005. Multicultural Politics: Racism, Ethnicity, and Muslims in Britain. Minneapolis: University of Minnesota Press.

Nelson, William E. 2000. Black Atlantic Politics: Dilemmas of Political Empowerment in Boston and Liverpool. Albany: SUNY Press.

Office of National Statistics. 2013. 2011 Census: Quick Statistics for England and Wales on National Identity, Passports Held and Country of Birth. London: Office for National Statistics.

Olsen, Marvin E. 1970. "Social and Political Participation of Blacks." American Sociological Review 35 (4): 682-97. 
Paschel, Tianna S. and Mark Q. Sawyer. 2008. "Contesting Politics as Usual: Black Social Movements, Globalization, and Race Policy in Latin America." Souls 10 (3): 197-214.

Paschel, Tianna S. 2016. Becoming Black Political Subjects: Movements and Ethno-Racial Rights in Colombia and Brazil. Princeton: Princeton University Press.

Rogers, Reuel R. 2006. Afro-Caribbean Immigrants and the Politics of Incorporation: Ethnicity, Exception, or Exit. Cambridge: Cambridge University Press.

Saggar, Shamit (ed.). 2004. Race and British Electoral Politics. London: UCL Press.

Saideman, Stephen M., David J. Lanoue, Michael Campenni, and Samuel Stanton. 2002. "Democratization, Political Institutions, and Ethnic Conflict: A Pooled Time-Series Analysis, 1985-1998." Comparative Political Studies 35 (1): 103-29.

Sanchez, Gabriel R., and Edward D. Vargas. 2016. "Taking a Closer Look at Group Identity: The Link Between Theory and Measurement of Group Consciousness and Linked Fate." Political Research Quarterly 69 (1): 160-74.

Sawyer, Mark Q. 2005. Racial Politics in Post-Revolutionary Cuba. Cambridge: Cambridge University Press.

Sawyer, Mark Q., Yesilernis Peña, and Jim Sidanius. 2004. "Cuban Exceptionalism: Group-Based Hierarchy and the Dynamics of Patriotism in Puerto Rico, the Dominican Republic, and Cuba." Du Bois Review 1 (1): 93-113.

Shelby, Tommie. 2005. We Who Are Dark: The Philosophical Foundations of Black Solidarity. Cambridge: Harvard University Press.

Simpson, Ludi. 2007. "Ghettos of the Mind: The Empirical Behaviour of Indices of Segregation and Diversity." Journal of the Royal Statistical Society: Series A (Statistics in Society) 170 (2): 405-24.

Smith, Brad W., and Malcolm D. Holmes. 2014. "Police Use of Excessive Force in Minority Communities: A Test of the Minority Threat, Place, and Community Accountability Hypotheses." Social Problems 61 (1): 83-104.

Smith, Candis Watts. 2013. "Ethnicity and the Role of Group Consciousness: A Comparison Between African Americans and Black Immigrants." Politics, Groups, and Identities 1 (2): 199-220.

Stokes, Atiya Kai. 2003. "Latino Group Consciousness and Political Participation." American Politics Research 31 (4): 361-78.

Telles, Edward Eric. 2004. Race in Another America: The Significance of Skin Color in Brazil. Princeton: Princeton University Press.

Tolnay, Stewart Emory, and Elwood M. Beck. 1995. A Festival of Violence: An Analysis of Southern Lynchings, 1882-1930. Champaign: University of Illinois Press.

Verba, Sidney, and Norman Nie. 1972. Participation in America: Political Democracy and Social Equality. New York: Harper.

Wacquant, Loïc. 2008. Urban Outcasts: A Comparative Sociology of Advanced Marginality. Cambridge: Polity.

Wade, Peter. 1997. Race and Ethnicity in Latin America. London: Pluto Press.

Waters, Mary C. 1994. "Ethnic and Racial Identities of Second-Generation Black Immigrants in New York City." International Migration Review 28 (4): 795-820.

White, Ismail K., Chryl N. Laird, and Troy D. Allen. 2014. "Selling Out?: The Politics of Navigating Conflicts Between Racial Group Interest and Self-Interest." American Political Science Review 108 (4): 783-800.

Woodward, Comer Vann. 1955. The Strange Career of Jim Crow. 3rd ed. New York: Oxford. 